\title{
Implementasi Metode TGT (Teams Games Tournament) Dalam Pembelajaran Pendidikan Agama Islam Guna Meningkatkan Keaktifan Siswa Di Sekolah Menengah Kejuruan Al Masruroh Puger
}

\author{
Badrut Tamami \\ Universitas Muhammadiyah Jember, Indonesia \\ Email: badruttamami@unmuhjember.ac.id
}

\begin{abstract}
The teaching and learning model developed by Robert Slavin is the Teams Games Tournament, which is a learning method by combining study groups with team competitions, cant also be use improve learning various concept for skills (Silberman, 2006). Learning with this method will stimulate students' activeness, because in Teams Games Tournament all students are required to actively voice their opinions, both lower group students and upper group student are requiire at works togeether solving problems given in learning.

The purpose of the implementation or application of the TGT method is none other than to increase student activity in absorbing and mastering the material presented in the teacheres on process teaching and learn activiti in Islamic Religious Education subjects at Al Masruroh Puger Vocational School, so that students do not experience boredom or boredom in receiving material using only the lecture method, the teams games tournament method is very appropriate and appropriate in overcoming students who are less active and are experiencing boredom for the teacher and learner progres.

The author conducted research with a qualitatife aproach and a field study research methodology which directly observed, interviewed students, and in the observations the researchers found several changes in students, the first students were more active, the second students felt happy because they could learn while playing, the third students can collaborate with friends in solving problems, so that the time in the teaching and learning process feels less and not boring because all students are involved in all activities of providing material in class.
\end{abstract}

Keyword: TGT Method, PAI Learning,Student activity

\section{Pendahaluan}

Tujuan dari pendidikan nasional salah satunya yaitu Mencerdaskan kehidupan generasi anak bangsa dan Negara serta memberantas kebodohan. Dalam Undang-Undang Dasar Negara No. 20 tahun 2003 tentang Sisdiknas, pendidikan merupakan upaya sadar dan terencana dalam mewujudken kondisi belajar dan pembelajaran yang efektif agar siswa bisa secara aktiv menggali dan mengembangkan potensi yang ada pada dirinya sehingga mempunyai sebuah kekuatan keagamaan, kecerdasan , sifat mengendalikan diri, berkepribadian, dan berakhlak yang mulia, serta keterampilan yang diperlukan dirinya, masyarakat, Negara (Rusman, 2012. Model Pembelajaran).

Dalam Pendidikan juga dilaksanakan secara individual maupun berkelompok melalui suatu proses pelatihan dan pembelajaran agar supaya terbentuk perubahan tingkah laku dan sikap. Perubahan tersebut juga dapat dikatakan bertambahnya keterampilan, 


\section{Badrut Tamami}

pengetahuan, dan budi pekerti, serta akhlak yang baik, rasa tanggung jawab hingga dapat mencapai kesejahteraan yang berdampak terhadap kemakmuran lingkungan keluarga, masyarakat, dan berbangsa.

Dalam tataran implementasi proses pembelajaran di tingkat SMK masih banyak di temui dan di dominasi oleh system belajar yang berpusat pada guru yang menggunakan model ceramah, tanpa adanya pola kreatifitas yang mengharuskan seorang pendidik dalam mengatur metode yang dapat membuat siswa bisa berperan aktif dan dengan mudah menyerap materi yang disampaikan tergantung kemampuan seorang guru dalam merancang proses pembelajaran didalam kelas dengan menggunakan metode yang tepat, cepat serta menyenangkan seperti teams games end tournament ini.

Guru sebagai perancang yang bisa mendesain dan mengarahkan model system pembelajaran sesuai dengan kurikulum dan kemampuan serta sarana media pembelajaran yang mendukung sangat menentukan kualitas dan hasil belajar peserta didik, seorang guru dituntut untuk kreatif dan mampu membuat siswa memahami dan mengerti apa yang seharusnya menjadi target penguasaan siswa dalam menyerap sebuah materi berdasarkan model dan metode pembelajaran dikelas yang di terapkan, sehingga menuju kepada era kemajuan sesuai dengan perkembangan zaman.

Ketepatan dan efektivitas dalam mengatur Strategi serta pemilihan metode pembelajaran yang pas dan sesuai untuk diterapkan dalam proses pembelajaran di sekolah dapat mengurangi rasa bosan dan kejenuhan seerta penuruan semangat siswa dalam menerima materi membutuhkan model pendekatan, dengan menjadikan siswa sebagai Studet center membuat pembelajaran dikelas menjadi kooperatif dan aktiv learning siswa merasa di hargai dalam memecahkan sebuah kesulitan yang alaminya sehingga dalam memahami materi yang dipelajarinya, (Sudjana, Nana. 1989. Dasar Proses Belajar Mengajar).

Didasarkan pengamatan dan studi lapangan di SMK Al Masruroh Puger, pada mata pelajaran PAI guru hanya menerangkan dan menggunakan metode ceramah dengan memakai media layar LCD proyektor dan papan tulis untuk menerangkan mata pelajaran kepada siswa. hanya 30\% praktek penggunaan metode yang melibatkan keaktifan siswa, meskipun penggunaan media LCD akan tetapi dalam pelaksanaan pembelajarannya masih tetap berpusat kepada pendidik dan masih sama dengan menggunakan metode ceramah.

Proses pembelajaran dikelas yang hanya berpusat pada pendidik dan menggunakan metode ceramah ini akhirnya menjadikan sebab siswa kurang aktif dan 
antusiasme serta komunikatif siswa dalam mengikuti pelajaran. Ada juga sebagian siswa yang tidak memperhatikan pelajaran saat guru menerangkan dan mengantuk, ada yang berbicara sendiri dengan teman sebangku, bermain handphone dan yang lainnya bahkan melakukan kegiatan yang sama sekali tidak menunjang kegiatan belajar di dalam kelas. Oleh karenanya berdasarkan informasi yang didapatkan dari guru pengampu (PAI), siswa cenderung pasif di dalam kelas saat guru menerangkan materi. Sebagian besar siswa bersikap acuh dan diam saat diberikan kesempatan untuk bertanya atau menjawab soal yang diajukan.

Pada saat diterapkannya model atau metode pembelajaran yang pas dan tepat agar supaya siswa dapat menerima materi secara utuh yang telah disampaikan oleh guru. meskipun tidak ada sama sekali siswa yang akan bertanya ketika telah diberikan sebuah kesempatan untuk bertanya oleh guru, hal itu tidak dapat dipergunakan sebagai barometer untuk menentukan siswa apakah sudah faham dan mengerti keseluruhan materi yang diajarkan oleh guru. Terbukti dari hasil tes ulangan ilmu hadist pada sanad dan matan siswa banyak yang tidak mengerti adanya difinisi sanad dan matan hadist yang sudah diajarkan oleh guru Agama dalam bab hadist.

Tiap kelas dari kelas X, XI, XII semua hampir sama dalam penggunaan model pembelajaran dalam menerangkan dan menyampaikan materi dalam mata pelajaran Agama Islam, masih menggunakan metode ceramah yang siswa hanya menjadi pendengar tanpa adanya komunikatif dan interaktif serta kooperatif yang dua arah.sehingga terkesan menjenuhkan dan membuat siswa kesulitan dalam menyerap materi agama karena tidak konsentrasi.

Memilih metode belajar yang pas dan tepat dibutuhkan kreatifitas guru sehingga mampu menciptakan proses yang menyenangkan dalam belajar di dalam kelas yang menyenangkan merupakan upaya yang dapat dikerjakan untuk mengantisipasi permasalahan dan kesulitan siswa dalam memahami materi tersebut. Pembelajaran Kooperatif Teams Games Tournament (TGT) adalah salah satu model atau metode pembelajaran yang bisa dipergunakan agar lebih menarik dan variatif kepada minat belajar siswa. Pembelajaran ini menekankan pada sebuah permainan dan bekerja sama dengan cara yaitu membagi siswa dalam kelompok.

Dalam pembelajaran Kooperatif ini keaktifan siswa dibagi beberapa kelompok kecil yang terdiri oleh 4 sampai dengan 6 orang siswa. Pembagian kelompok kecil ini diharapkankan agar tiap siswa untuk dapat berkolaborasi dan berinteraksi dengan sesama 


\section{Badrut Tamami}

teman, maupun lingkungan, guru dan semua pihak yang terlibat selama proses pembelajaran dikelas. Dengan demikian tujuan akhir dari proses pembelajaran tersebut dapat dicapai atas karena keterlibatan siswa menjadi semakin lebih aktif, memiliki semangat untuk belajar mandiri serta memiliki persiapan dalam mengikuti prosesi pembelajaran di sekolah.

\section{Model pembelajaran TGT merupakan salah satu model}

pembelajaran yang efektif dan kooperatif yang mudah diterapkan kepada siswa, karena siswa menjadi pusat dari aktivitas pembelajaran, guru hanya mengatur jalannya kegiatan tersebut, seluruh peserta didik dilibatkan dalam aktivitas pembelajaran tanpa harus membedakan status, menjadikan teman sebagai tutor sebaya dan membuat unsur permainan yang menyenangkan.

Terdapat lima unsur komponen utama dalam kegiatan TGT dikelas yaitu (Slavin, 1995:84-88)

\section{a. Class Presentation}

Setiap siswa mempunyai kesempatan untuk maju ke depan guna mempresentasikan materi yang dipelajarinya, sedangkan kelompok yang lain mendengarkan serta menyiapkan sebuah rangkuman dan pertanyaan dari hasil keterangan pemateri, kemudian saling bergantian dalam presentasi di kelas antar kelompok, berjalannya diskusi guru lah yang mengatur pembagian kelompok masing-masing, dan hal ini bisa dilakukan dengan system pertemuan langsung tatap muka di kelas.

b. kelompok (Teams)

Masing masing kelompok mempersiapkan materi yang akan didiskusikan, menunjuk satu orang sebagai ketua kelompok yang akan mengatur dan menjelaskan kepada teman lainnya, dan apabila dari beberapa pertanyaan yang diajukan oleh temannya tidak bisa terjawab maka guru lah yang akan menjadi tempat untuk menjawab pertanyaan tersebut.

Anggota tim atau Kelompok terdiri dari 4 sampai dengan 5 orang siswa yang mempunyai karakter dan kemampuan heterogen dinilai dari prestasi dikelas, jenis kelamin, etnik dan ras. Kelompok berfungsi sebagai pendalaman materi bersama teman sejawat kelompoknya dan mempersiapkan seluruh anggota kelompok agar lebih baik dan maksimal pada saat edukasi permainan (games).

c. Edukasi Permainan (Games Education) 
Model Permainan tidak lain dirancang guna untuk mengetahui tingkat pemahaman siswa tentang materi yang diajarkan setelah mengikuti sesion presentasi di kelas dan belajar secara berkelompok. Permainan atau Game berdasar atas pertanyaanpertanyaan yang telah dirancang oleh guru maupun siswa lainnya untuk mengetahui tingkat pemahaman yang didapat oleh siswa dari penyajian presentasi di kelas dan belajar kelompok sebelumnya. game berupa kuis atau pertanyaan sederhana bernomor. Semua siswa memilih kartu yang sudah bernomor dan disuruh menjawab kuis atau pertanyaan yang sudah dipersiapkan sesuai dengan nomor masing-masing. Kemudian bagi Siswa yang dapat menjawab dengan benar pertanyaan maka akan mendapatkan point berupa skor.

d. Pertandingan (Tournament)

Turnament yang dimaksud merupakan suatu lomba atau pertandingan antar siswa yang beranggotakan beberapa kelompok. Waktu yang digunakan dalam turnamen biasanya dilaksanakan setelah guru memberikan penjelasan materi dan juga setelah siswa melaksanakan belajar kelompok. Pada permulaan turnamen, guru memberikan dan menugaskan siswa untuk berpindah pada sebuah meja turnamen yang sudah dipersiapkan sebelumnya oleh guru, dalam menentukan meja turnamen ini berdasarkan hasil pengamatan dan penilaian guru kelas dan dari hasil tes ujian sebelumnya (dalam pertandingan ini terdapat 5 meja kelompok yaitu meja $\mathrm{A}$, meja $\mathrm{B}$, meja $\mathrm{C}$, meja $\mathrm{D}$ dan $\mathrm{E}$ yang terdiri dari 3 sampai dengan 4 orang siswa secara acak).

Dalam praktek penjelasan secara sederhana bisa digambarkan dengan lomba cerdas cermat yang sering dijumpai, masing-masing siswa mengambil nomor untuk mendapatkan sebuah pertanyaan yang sudah dipersiapkan oleh guru, setelah itu siswa menjawab pertanyaan tersebut, dan apabila tidak bisa menjawab maka dibantu oleh teman sejawat yang dalam satu kelompok, jika apabila masih belum menemukan sebuah jawaban kelompok tersebut, maka hasil akhir gurulah yang akan menjawab pertanyaan, akan tetapi kelompok A tidak mendapatkan nilai atau skor tambahan.

Adapun pelaksanaan kegiatan ini menggunakan metode pendekatan Kualitatif, yaitu: Penelitian atau riset ini merupakan langkah awal atau pemula yang tidak lain untuk mendeskripsikan upaya yang dilakukan dalam rangka memberikan kualitas kepada siswa melalui model pembelajaran metode TGT dalam PAI guna meningkatkan keaktifan siswa 


\section{Badrut Tamami}

di SMK Al Masruroh Puger Jember. Sedangkan Pendekatan yang dilakukan pada penelitian kali ini adalah sebuah pendekatan deskriptif kualitatif karena (1) peneliti merupakan subjek yang bertindak sebagai instrumen utama, dan karena disamping sebagai pengumpul terkait data dan juga menganalisa data, peneliti juga terlibat langsung dalam proses penelitian studi lapangan, (2) mempunyai kemampuan dalam setting (natural setting), data yang dihasilkan dari lembaga SMK Al masruroh akan dipaparkan dan dinarasikan sesuai dengan yang terjadi dilapangan, (3) hasil dari penelitian ini bersifat deskriptif naratif, karena data yang didapat akan dikumpulkan bukan berupa angka, melainkan dalam bentuk kalimat narasi, (4) mengutamakan proses sekaligus hasil yang maksimal, (5) terdapat batasan masalah yang ditemukan dalam fokus penelitian lapang, dan (6) menganalisa data yang mengarah kepada induktif.

Terdapat beberapa lembar instrumen yang diperlukan dalam menganalisa penelitian ini, sebagaimana berikut :

1. Perencanaan (Plan)

Dalam tahapan ini diperlukan planning penyusunan atau rencana sebuah tindakan berupa persiapan strategi pembelajaran yang efektif dan kooperatif yaitu model TGT.

a. RPP (Rencana Pelaksanaan Pembelajaran).

Pada penyusunan RPP pendidik dan peneliti perlu menetapkan langkah apa saja yang akan dilaksanakan dalam proses pembelajaran di kelas, serta aktifitas kegiatan apa saja yang kiranya perlu dikerjakan oleh siswa dalam mengimplementasi kualitas pengetahuan dan pemahaman yang direncanakan. komponen yang terdapat di dalam RPP antara lain yaitu indicator keberhasilan, Standar kompetensi, kompetnsi Dasar, materi ajar, tujuan pembelajaran, metode pembelajaran, dan strategi/ prosedur pembelajaran kelas.

b. Kelompok (Grouping)

Dalam pelaksanaannya system model belajar TGT yaitu, siswa dibagi menjadi beberapa group atau kelompok yang terdiri 4 sampai dengan 5 orang. Dalam hal ini guru yang membagikan masing-masing kelompok siswa sebagai pihak yang mengerti kemampuan dan karakter siswa yang beragam dan heterogen. setelah selesai membagi guru menyuruh siswa untuk berdiskusi dan belajar bersama dalam mempersiapkan jawaban dari sebuah pertanyaan atau kuis yang sudah di persiapkan oleh guru setelah memberikan materi. 
Siswa bisa dengan leluasa mendiskusikan dengan teman sejawat dalam kelompok masing-masing tanpa perlu khawatir dan malu apabila belum mengerti dan memahami materi yang sudah di sampaikan oleh guru, karena yang dihadapi untuk berdiskusi ialah tutor sebaya dan teman sekelas.

\section{Tindakan (Action)}

Tindakan atau aksi merupakan wujud dari implementasi pembelajaran model Teams Games Tournament yang telah direncanakan terlebih dahulu. sedangkan terdapat tiga bagian lembar instrumen yang diperlukan dalam mengukur tingkat keaktifan siswa yaitu secara keseluruhan kelas, berkelompok, dan secara individual.

Dalam aspek pengukuran keaktifan siswa dalam kelas perlu menggunakan lembar observasi keaktifan dan keterlibatan kegiatan belajar siswa, sedangkan dalam hal pengukur keaktifan siswa di dalam kelompok belajar diperlukan instrumen yaitu lembar observasi kegiatan belajar siswa dalam diskusi dan kerja sama kelompok.

3. Pengamatan (Observasi)

Arikunto, 1998:139 menjelaskan dalam bukunya bahwasanya teknik pengamatan atau observasi perlu dilakukan secara teliti dan sistematis, cara pengumpulan data harus melalui sebuah observasi lapangan yang dilakukan sendiri oleh penulis pada kelas yang akan dijadikan uji coba atau sampel untuk mendapatkan gambaran secara langsung berupa kegiatan pembelajaran siswa di dalam kelas.

Lembar instrumen yang dibutuhkan dalam kerangka penelitian ini juga mengacu kepada Tantra (2006:15) dan Bergerman, 1992 yang membagi dalam tiga kelompok, yaitu: lembar instrumen observasi guru (observing teacher), lembar instrument observasi kelas (observing classroom), dan lembar instrumen observasi perilaku aktifitas siswa (observing student).

\section{Pengamatan (pra) penelitian}

1) lembar Instrumen observasi guru (observing teacher)

Dalam tulisan ini, pengamatan terhadap aktivitas guru dalam proses belajar mengajar dikelas dengan cara membuat booknote atau catatan anekdot. Catatan tersebut berisikan tentang penjabaran yang sifatnya lebih detail dan spesifik mengenai segala aktivitas yang dilakukan oleh guru dikelas selama pembelajaran berlangsung.

2) lembar Instrumen observasi kelas (observing classroom)

Dalam penulisan ini, pengamatan terhadap aktifitas kegiatan kelas dalam KBM kegiatan belajar mengajar yang dilakukan peneliti yaitu dengan membuat catatan 


\section{Badrut Tamami}

anekdot yang berisi tentang ulasan dan penjabaran yang bersifat lebih spesifik dan intensif mengenai aktivitas kegiatan siswa yang terjadi di kelas selama pembelajaran.

3) Lembar Instrumen observasi perilaku siswa (observing student).

Dalam penulisan ini, lembar observasi terhadap aktivitas kegiatan siswa dalam proses kegiatan belajar mengajar yang dilakukan oleh peneliti dengan cara membuatkan catatan anekdot berisi tentang penjabaran yang bersifat lebih spesifik dan detail tentang aktivitas kegiatan siswa selama masa pembelajaran di kelas dan di sekolah.

\section{Hasil Kegiatan}

Pada proses kegiatan mengajar dikelas yang dilaksanakan setiap hari memberikan dampak perubahan dan diharapkan bisa mendapatkan hasil belajar yang memuaskan terhadap perkembangan dan pemahaman siswa sehingga dalam penelitian ini 3 unsur atau komponen yaitu aspek kognitif, afektif dan psikomotorik. Yang didasarkan pada teori Taksonomi Bloom (Sujana, 1989:3) dengan rincian detail sebagi berikut:

a) Aspek Kognitif yang meliputi antara lain:

1) daya ingat dan ilmu pengetahuan

2) daya serap dan Pemahaman

3) implementasi atau Penerapan

4) daya Analisis dan kritis

5) daya Sintesa

6) proses Evaluasi pembelajaran

b) Ranah Aspek Afektif yang meliputi antara lain:

1) Aspek Stimulan

2) hasil Jawaban

3) aspek Penilaian

4) keaktifan berorganisasi

5) sikap dan Karakteristik

c) Aspek Psikomotorik

Keterampilan, kreatifitas, dan kemampuan dibidang fisik merupakan ranah dari aspek Psikomotorik, yang menggabungkan antara sikap dan kreatifitas siswa selain itu daya saing dalam berkompetisi sangat diperlukan adanya aspek kemampuan psikomotorik 
karena mengetahui kekurangan dan kelebihan masing-masing siswa yang pada akhirnya mampu memenangkan pertandingan.

Dalam Pengalamannya penulis sendiri sebelum adanya musim pandemi berusaha mengamati pelaksanakan Model belajar Teams Games Tournament (TGT) untuk beberapa materi pada mata pelajaran PAI baik di kelas X, XI, XII. Model pembelajaran TGT merupakan salah satu diantara model variasi pembelajaran yang efektif dan kooperatif serta inovatif yang mudah diberikan kepada siswa, dikarenakan melibatkan kreativitas keseluruhan murid tanpa adanya perbedaan pada status, menjadikan teman sebagai mentor sejawat dan terdapat aspek permainan yang menyenangkan sangat berbeda sekali dengan metode pembelajaran ceramah yang biasa kita jumpai, peran seorang pengajar atau guru sangat mendominasi sementara para siswa hanya menjadi objek pendengar, sehingga beberapa siswa saja yang mampu dan faham serta bertindak aktif dalam proses pembelajaran dikelas. Namun mayoritas para siswa terkesan diam dan pasif serta enggan untuk bertanya dan respon balik kepada guru tentang materi yang sudah diajarkan, serta menjawab maupun menanggapinya.

Keaktifan siswa dalam kelas merupakan kelebihan penerapan metode pembelajaran TGT yang berbeda tentunya dengan model pembelajaran biasa. Dalam hal Kegiatan belajar mengajar guru PAI hanya memberikan penguatan materi yang selanjutnya siswa yang harus menentukan penuh kegiatannya bersama teman sebaya, karena apa yang dipelajari dan didapat dari guru akan diterapkan dalam bentuk kuis, dan skor kuis mereka akan memberikan skor kelompoknya.

Pembagian kelompok Pada tahapan kedua yaitu dilanjutkan dengan kegiatan berkelompok, empat sampai dengan lima orang siswa belajar di dalam kelas, (terdiri dari berbagai etnis, jenis kelamin dan tingkat kepandaian,) setelah pendidik atau guru selesai memberikan mata pelajaran (bahan bacaan). Siswa diharapkan bisa bekerja sama dalam kelompok masing-masing dan saling membantu satu sama lain untuk memahami dan mencermati materi pelajaran.

Masing-masing kelompok menunjuk perwakilan untuk mempresentasikan hasil kerja samanya di depan kelompok lain, kemudian saling menguatkan argumentasi atau alasan dalam menemukan perbedaan pemahaman dari materi pelajaran yang telah disampaikan oleh guru, masing masig anggota kelompok membantu dengan memberikan masukan dan tanggapan, sehingga dalam prosesnya semua siswa dilibatkan untuk lebih 


\section{Badrut Tamami}

aktif dan komunikatif dalam pembelajaran pendidikan Agama islam di SMK Al masruroh Kasiyan timur Puger Jember.

\section{Mata Pelajaran Pendidikan Agama Islam}

Merupakan sebuah terobosan baru dalam hal metode pembelajaran yang menyenangkan, metode TGT memberikan warna bagi proses pembelajaran pada mata pelajaran PAI yang kesannya dari dulu hanya menggunakan metode ceramah, dalam implementasinya siswa sangat antusias dan aktif dalam kelas pada saat diterapkannya metode teams games dan tournament, siswa merasa tertantang dan dilibatkan secara langsung untuk aktif berperan dalam menyelesaikan sebuah pertandingan melawan tim atau kelompok diskusi, masing-masing mempersiapkan dengan sangat baik materi yang akan di pertandingkan dan diskusi kelompok.

Dalam materi ilmu Fiqh guru PAI hanya memberikan sekilas rangkuman dasar tentang dasar hokum, tata cara dan toeri pembanding, kemudian guru membentuk beberapa kelompok untuk mendiskusikan materi Fiqh tersebut, disetiap kelompok mempunyai hak untuk bertaya dan menjawab serta menjelaskan dan mendapatkan nilai sesuai dengan keaktifan anggota kelompoknya masing-masing.

Mata pelajaran Pendidikan Agama Islam dalam bab tertentu memang memerlukan adanya praktek tidak hanya sebatas teori, salah satu contohnya dalam materi mengurus jenazah dan memandikannya, dalam penggunaan metode TGT pada bab ini semua siswa dilibatkan untuk dapat bekerja sama pada masing-masing kelompoknya agar supaya bisa dan memahami betul cara mengurus jenazah dan memandikannya sesuai dengan apa yang telah dipelajari sebelumnya.

\section{Kesimpulan}

Dalam implementasi metode TGT diperlukan kerja sama semua elemen stekholder sekolah SMK Al Masruroh Puger khususnya siswa kelas X, XI, XII untuk aktif dalam mengikuti pembelajaran dikelas, memberikan respon yang positif dan peran guru PAI sebagai manajerial yang mengawasi jalannya pelaksanaan metode pembelajaran TGT untuk bisa selalu memotivasi siswa, dalam pelaksanaan metode TGT siswa menjadi pelaku utama dalam proses pembelajaran dikelas. 
Implementasi Metode TGT (Teams Games Tournament) 


\section{Badrut Tamami}

\section{Daftar Pustaka}

Agus Setiawan,2019. Merancang Media Pembelajaran PAI di Sekolah. Jurnal keagamaan pendidikan, dan kemasyarakatan Darul Ulum. Volume 10, Nomor 2

Etin \& Raharjo, Solihatin. 2007. Coperative Learrning: Analisa Model Pembelajaran. Jakarta: PT. Bumi Aksara

Etta Mamang dan Sopiah, 2010. Metodologi Penilitian Pendekatan Praktis dalam Penelitian. Yogyakarta, C.V. Andi Offset

Himmatul Husniyah. 2021. Pengaruh Profesionalisme Guru Terhadap Peningkatan Prestasi Belajar Siswa Kelas X Di Madrasah Aliyah 02 Pondok Modern Paciran Lamongan. Jurnal Annaba STIT Muhammadiyah Paciran. Vol. 4 No. 1

Idzi’ Layyinnati. 2018. Pengaruh Penerapan Media Benda Asli Pada Mata Pelajaran Matematika Terhadap Hasil Belajar Siswa Kelas 1 Di Madrasah Ibtidaiyah. Jurnal Annaba STIT Muhammadiyah Paciran. Vol. 7 No. 2

Idzi’ Layyinnati. 2021. Pengaruh Penggunaan Media Gambar Untuk Meningkatkan Hasil Belajar Bahasa Arab Siswa Kelas VII Di Madrasah Tsanawiyah 12 Palirangan. Jurnal Annaba STIT Muhammadiyah Paciran. Vol. 7 No. 1

Intan Kharismayanti. Penerapan Model Cooperative Learning Tipe Scramble Untuk Meningkatkan Aktivitas Dan Hasil Belajar PKn Siswa Kelas IV SD Negeri 10 Metro Pusat. Jurusan Ilmu Pendidikan Fakultas Keguruan dan Ilmu Pendidikan Universitas Lampung

Maftuhah. 2021. Pengaruh Metode Tanya Jawab Terhadap Prestasi Belajar Siswa Mata Pelajaran Akidah Akhlak Kelas IV Di Madrasah Ibtidaiyah Muhammadiyah 06 Brondong Lamongan. Jurnal Annaba STIT Muhammadiyah Paciran. Vol. 7 No. 1

M. Chotibuddin. 2021. Pengaruh Metode Cooperative Type Jigsaw Terhadap Peningkatan Hasil Belajar Siswa Mata Pelajaran Pendidikan Agama Islam Di Kelas VI Madrasah Ibtidaiyah Muhammadiyah 09 Kranji Lamongan. Jurnal Annaba STIT Muhammadiyah Paciran. Vol. 7 No. 1

M. Chotibuddin. 2017. Penggunaan Metode Inkuiri Dalam Peningkatan Hasil Belajar Bahasa Inggris Di Kelas VII Madrasah Tsanawiyah Muhammadiyah 17 Paciran. Jurnal Annaba STIT Muhammadiyah Paciran. Vol. 3 No. 2

Rusman, 2012. Model Pembelajaran. Jakarta: P.T. Raja Grafindo Persada 
---------, 2013. Model-Model Pembelajaran Mengembangkan Profesionalime Pendidik. Jakarta: P.T. Rajagrafindo

Robert E. Slavin, 2005. Cooperative Learning Teori, Riset dan Praktik. Bandung: Nusa Media

Saifuddin Zuhri Qudsy dan Achmad Fawaid, 2013. Cooperative Learning. Yogyakarta: Pustaka Pelajar

Subhan Adi Santoso, Ali Mustofa, 2019. Ilmu Pendidikan Islam Era Industri 4.0. Malang: Media Sutra Tiga

Subhan Adi Santoso, 2020. Media Pembelajaran Pendidikan Agama Islam Era Industri 4.0. Yogyakarta: Deepublish

Subhan Adi Santoso, M. Chotibuddin, 2020. Pembelajaran Blended Learning Masa Pandemi. Pasuruan: Qiara Media

Subhan Adi Santoso, Himmatul Husniyah, 2021. Pendidikan Agama Islam Berbasis IT. Yogyakarta: Zahir Publishing

Subhan Adi Santoso, 2017. Pengaruh Kompetensi Pedagogik Guru Terhadap Prestasi Belajar Siswa Kelas XI Mata Pelajaran PAI Di SMKN 13 Malang. Jurnal Tamaddun: Vol. 18 No. 2

Subhan Adi Santoso, 2017. Implementasi Kurikulum 2013 Dalam Kegiatan Pembelajaran PAI Di SMKN 13 Malang. Jurnal Annaba STIT Muhammadiyah Paciran. Vol. 3 No. 1

Sudjana., Nana. 1989. Dasar-dasar Proses Belajar Mengajar. Bandung: Sinar Baru

Sulasteri, Susi,. 2009. Peneerapan Metode Pembelajaran Kooperatif Tipe TEAMS GAMES TOURNAMENTS (TGT) untuk Meningkatkan Kektifan Belajar Siswa pada Mata Pelajaran Ekonomi. Skripsi. Yogyakarta:Universitas Sanata Dharma

Sukardie, 2013. Metode Penelitian Tindakan Kelas IImplementasi dan Pengembangannya. Jakarta: Bumi Aksara

Sumandii, 2013. Psikologi Pendidikan. Jakarta: Rajawali Pers

Sunantri, S Mulyani. 2001. Strategi Belajar Mengajar. Bandung: CV Maulana

Slavin,, R.E, 1995. Cooperative Learning: Theory, Research, and Practice (2nded.). Boston: Aliyn and Bacon

Trianto, 2012. Mendesain Model Pembelajaran Inovatif-Progresif. Jakarta: Kencana Prenada Media Group 


\section{Badrut Tamami}

-------, 2013. Model Pembelajaran Terpadu Konsep, Strategi, dan Implementasinya dalam Kurikulum Tingkat Satuan Pendidikan (KTSP). Jakarta: PT Bumi Aksara https://ekocin.wordpress.com/2011/06/17/model-pembelajaran-teams-games-

tournaments-tgt-2/ (diakses pada hari kamis, tanggal 17 Februari 2022)

14 Volume 8 No. 1, 1 Maret 2022 